\title{
Influential Factors Responsible for Profitability: A Technical Study on Commercial Banks in Bangladesh
}

\author{
S. M. Akber \\ Lecturer \\ Department of Business Administration \\ Ranada Prasad Shaha University, Bangladesh \\ E-mail:sayemkane@gmail.com
}

\begin{abstract}
This paper explores how many internal and external factors from 2007-20I7 affect the competitiveness of commercial banks in Bangladesh. Many bank-specific variables are used to achieve the goals as internal factors, and macroeconomic variables are used as external factors. A sample of seven commercial banks will be used for this purpose. Return on equity is used as a proxy for profitability and capital adequacy, the size of asset quality banks, investment control, liquidity, resource structure, and economic indicators are used as proxies for the independent variable. The paper's overview findings show that asset structure, capital adequacy, and asset quality are the key factors in Bangladesh's profitability for the commercial bank. The paper's outcome indicates that if commercial banks are more worried about these factors, they could produce a better return on the competitive market.
\end{abstract}

Keywords: Profitability, ROA, GDP, Banking Performance.

\section{Introduction}

The financial system of Bangladesh consists of scheduled or non-scheduled banks, non-bank banks, insurance companies, asset managers, microfinance institutions, commercial banks, joint-stock companies, brokerage houses, exchanges of shares and credit rating firms under the supervision of various regulators. There are currently 7 state-owned commercial banks (SCBs), 2 specialized development banks (SDBs), 40 domestic private commercial banks (PCBs), 9 foreign commercial banks (FCBs), 3 non-scheduled banks, and 35 non-bank financial institutions (Bangladesh Bank, 2018) in Bangladesh.

In the banking industry, commercial banks play an important role and there are currently 59 commercial banks. These banks have worked successfully through conventional banking services in Bangladesh for the last four decades. Although the basic principle of commercial banks is to transfer the fund from the surplus to deficit unit nowadays they are being considered as a business conglomerate. Commercial banks are being considered as the lifeblood of the banking system.

Bank profitability is regarded throughout the world as a major topic for analysis. After the 2008 financial crisis and the Basel III framework that demonstrated the performance of the bank had been applied. As competition has increased substantially in the banking industry, Bangladesh needs some academic studies to find out the influential drivers of profitability

\section{Literature Review}

The research was conducted on the bank and macroeconomic factors common to various economies around the globe. The profitability of the bank is used to express both internally and externally. Internal factors can be called micro factors or bankspecific factors and external factors can be described as macroeconomic factors that affect banks ' profitability.

The method POLS (Polished Ordinary Least Square) has been used by (Gul, Irshad \& Zaman, 20II) to depart from the data used by the Top I5 Pakistani commercial banks from 2005 to 2009 to identify whether there is any link between the banking specific and macroeconomic properties on the profitability of the financial sector. The results of these researches were shown by a positive impact on all 3 indicators of profitability, i.e., ROA, ROE, and NIM, on assets, loans, equity $\&$ deposit.

There are certain factors for banks that have a major impact on bank profitability and work (Mirzaei \& Mirzae, 20I I) has been carried out, confirming that there is a non-linear relationship between size and profitability. The findings of their analysis suggest that the key determinants of productivity are capital capacity, liquidity, and performance. Besides, they concluded that the impact of inflation is, at least for the time considered, negative for the Middle East.

Acaravci \& Calim (2013) carried out research using commercial banks in the Turkish banking sector, using a sample period from 1998 to 201 I. Total credit / total assets, total deposits / total assets, commission / total expenses, total wages and commission income / total assets are the bank-specific determinants that were considered to have profitable effects, total wageto-total assets / total assets and total assets logarithm. The study's macroeconomic drivers were the real gross domestic product, 
inflation rate, real currency, and real interest. The findings of this study suggested that the bank-specific factors had more impact on the profitability of banks than macroeconomic factors.

Dey (20I4) used a gradual method for regression to examine the financial performance of listed private commercial banks in Bangladesh in terms of profitability, whereby certain variables were considered to be an influential indicator of profitability, such as asset quality, operational performance, and bank size. The liquidity position, on the other hand, has a positive but insignificant profitability impact.

Nisar, Susheng, Ahmed, \& Ke (2015) examined how the profitability of the Pakistani banking sector by applying Pooled Ordinary Least Square (POLS) regression technology influences banking specific, industry-specific and macroeconomic factors. The discoveries indicated that the gainfulness of the Pakistani financial division is contrarily influenced by subsidizing cost liquidity, non-performing credits, and managerial costs and decidedly influenced by non-finance based administrations, capital ampleness, banking area improvement, and monetary development.

Noman (2015) inquired about the benefit of seven Islamic banks in Bangladesh from 2003 to 2013 utilizing bankexplicit and macroeconomic determinants where they investigated ROAA, ROAE, and NIM while ROAA is discovered increasingly favored productivity pointer for the Islamic banks in Bangladesh. The result found that credit chance, credit proportion, cost-effectiveness, and gainfulness capitalization have a critical negative effect while the size of the bank has an extensive positive effect on the benefits of Bangladeshi Islamic banks.

Hosain \& Ahamed (2015) led an examination in which the fixed impact model was utilized and two-factor income (Tin and NII), asset value (NPL), management efficiency (OPEX), capital force (CAP) impacts of the industry (SIZE) and resource structure (DPST) were found to be significant for ROA.

A study was conducted by (Hossain \& Ahamed 2015) where they used the fixed-effect model and found in case of ROA, two earnings variables (TIN and NII), asset quality (NPL), management efficiency (OPEX), capital strength (CAP) industry impact (SIZE), and asset structure (DPST) have been found to be significant. For ROE, the earnings indicators, capital strength, and industry impact have a positive relationship with ROE. On the outcome it was found that only NPL had a negative relationship with ROE among the statistically significant predicting variables For NIM, TIN, OPEX, and CAP, there is a positive relationship but NII has a negative relationship.

There are also so many gaps in the literature review in determining the variables that are key to the competitiveness of Bangladesh. Profitability considerations in Bangladesh's business banking sector remain less exploratory. The number of studies in this field is not sufficient to compare the requirement. This paper aims to contribute practical research to detect and fill the research gaps in this sector, which would affect profitability.

\section{Objectives of the Research}

- To find out the influential factors those are responsible for the profitability of commercial banks in Bangladesh.

- To explore how much it effects on profitability of commercial banks in Bangladesh.

\section{Methodology \\ 4.I Sampling}

This paper emphases the assessment of the factors of bank profitability in Bangladesh. Here the Bank Specific Interest Factors are used to determinate the bank's profitability. For this a sample of 07 (seven), Private Commercial Banks were considered with 77 observations for the period of 2007-2017. Non-Conventional banks were excluded to maintain the homogeneity of the sample. A convenient and judgmental sampling technique is used in selecting commercial banks. Here other variables are selected based on previous academic studies.

\subsection{Sources and Collection of Data}

As this type of research design is descriptive so secondary data were used for justifying the intention of the paper. Here the usable data are collected from published annual reports of the sample banks.

\subsection{Processing \& Analyzing Data}

Here data were analyzed by using statistical software SPSS 20 version to get a reliable output. A simple model has been used to find out the factors of the profitability of commercial banks. The model is given below:

$$
\mathrm{Y}=\alpha_{D}+\beta_{1} X_{1}+\beta_{2} X_{2}+\beta_{3} X_{3}+\beta_{4} X_{4}+\beta_{5} X_{5}+\beta_{6} X_{6}+\beta_{7} X_{7}+€
$$

Where,

$Y_{1}=$ Profitability of the Commercial Banks

$X_{1}=$ Bank Size 
$X_{2}=$ Capital Structure

$X_{3}=$ Asset Quality

$X_{4}=$ Economic Indicator

$X_{5}=$ Capital Adequacy

$X_{6}=$ Liquidity Condition

$X_{7}=$ Cost Management

$\alpha_{D}=$ Constant value

$\beta=$ Slopes of the independent variables.

$€=$ Represent the error term.

Dependent Variable: To measure the commercial bank's profitability, returns on assets (ROA) are used as a dependent variable. This ratio demonstrates how efficiently a bank makes use of its resources for revenue generation.

Independent Variable: This paper includes six bank-specific that are used as an internal variable and only a single external variable is used to conduct the study.

Table I. Variables

\begin{tabular}{lllll}
\hline Variables & Notation & Variables & Variable Description \\
\hline Dependent Variables & ROA & Return on Asset & Net income after tax/ total assets \\
\hline & & CA & Capital Adequacy & Total equity/ total assets \\
\cline { 2 - 4 } $\begin{array}{l}\text { Independent } \\
\text { variables }\end{array}$ & $\begin{array}{l}\text { Bank } \\
\text { Specific } \\
\text { factors }\end{array}$ & CS & Bank Size & Natural log of total assets \\
\cline { 2 - 4 } & & Capital Structure & Total deposits/ total assets \\
\cline { 2 - 4 } & & Cost management & Total operating expenditure/ total assets \\
\cline { 2 - 4 } & LC & Asset quality & Investments/ total assets \\
\cline { 2 - 4 } & $\begin{array}{l}\text { External } \\
\text { factors }\end{array}$ & EI & Economic indicator & GDP growth rate \\
& & & Cash/total assets \\
\end{tabular}

Capital Adequacy is an internal funding source that is used as a productivity calculation factor. An increase in productivity can lead to a capital increase. Retained earnings are a measure of the capital of a bank. It is calculated by an overall equity ratio divided by total assets.

Deposits are the lifeblood of bank financing that is considered to be the most influential factor influencing the profitability of the bank. By calculating the total deposits divided by total assets, it is used to find the capital structure.

Investment is the most important determinant of the competitiveness of the bank. The higher investment would, potentially, provide the higher income from the bank. It is used by calculating total investments to total assets to find the quality of the assets.

The bank's size is determined by the total asset's natural logarithm. It is regarded as an internal determinant of the profitability of the bank. By managing their total assets and liabilities efficiently, large banks can minimize their fixed costs.

Total cash to total assets is measured by the liquidity condition. Liquidity determines the capacity of the bank to comply with its payment obligations.

Cost Management indicates how efficiently a bank manages its operating expenditure. It shows the efficiency of management. Banks can increase their profitability by efficiently using their operating expenditure.

Economic Indicator (GDP Growth) is measured through the economic condition of a country. Economic development increases the borrowers ' solvency as well as the banks ' profitability 


\section{Research Hypothesis}

The following hypothesis is assessed based on the experiment's objectives.

$\mathrm{H}_{1}$ : The relationship exists between the size of the bank and profitability.

$\mathrm{H}_{2}$ : There is a connection between the structure of capital and profit.

$\mathrm{H}_{3}$ : There is a connection between the quality of assets and profitability.

$\mathrm{H}_{4}$ : There is an association between economic indicator and profitability.

$\mathrm{H}_{5}$ : There is an association between capital adequacy and profitability.

$\mathrm{H}_{6}$ : There is an association between liquidity condition and profitability.

$\mathrm{H}_{7}$ : There is an association between cost management and profitability.

\section{Data Analysis and Findings}

The ultimate goal of this paper is to identify both internal and external factors that affect the profitability of the bank in Bangladesh. As always, there are three aspects to the data analysis. Part one of the quantitative analysis involves mean $\&$ standard deviation. In the second part, the matrix of Pearson correlation and the statistics of collinearity are shown. Multiple regression analyses are shown in the third part. The combination of two or more predictor (independent) variables and one dependent variable is observed through multiple regressions (Krishnaswany et al., 20I I).

\section{I Descriptive Statistics}

Table 2 demonstrates the results of the descriptive statistics for the regression model's key factor. As key figures, standard deviation, minimum and maximum values have been registered.

Table 2. Descriptive Statistics

\begin{tabular}{lllllll}
\hline Variables & $\mathrm{N}$ & Range & Minimum & Maximum & Mean & Std. Deviation \\
\hline ROA & 77 & $\mathrm{I} 4.4 \mathrm{I}$ & $-\mathrm{I} 0.85$ & 2.98 & .6283 & $2.13 \mathrm{I5}$ \\
\hline NLBS & 77 & $4.7 \mathrm{I}$ & 8.59 & $\mathrm{I3} .14$ & $\mathrm{I} 0.562 \mathrm{I}$ & $\mathrm{I} .1635$ \\
\hline $\mathrm{CS}$ & 77 & 78.50 & 7.65 & 87.69 & $74.32 \mathrm{I0}$ & $\mathrm{I} 0.0428$ \\
\hline $\mathrm{CA}$ & 77 & $\mathrm{I} 23.18$ & $-\mathrm{I} 06.58$ & $\mathrm{I} 4.56$ & $.6 \mathrm{I} 20$ & 29.4438 \\
\hline $\mathrm{CM}$ & 77 & 8.89 &. $\mathrm{I} 6$ & $8.6 \mathrm{I}$ & 2.0538 & $\mathrm{I} .6596$ \\
\hline $\mathrm{AQ}$ & 77 & 74.67 & 6.05 & 78.62 & $70.105 \mathrm{I}$ & 9.5064 \\
\hline $\mathrm{LC}$ & 77 & $\mathrm{I} 8.95$ & .48 & $\mathrm{I} 8.3 \mathrm{I}$ & 7.9645 & 3.4380 \\
\hline EI & 77 & 2.00 & 4.95 & 6.54 & 6.1345 & .5453 \\
\hline Valid N (listwise) & 77 & & & & & \\
\hline
\end{tabular}

Here the findings say that the standard deviation of ROA is 2.13. The value is higher than the mean value (.6283). The standard deviation of CA (29.44) is also higher than the average value (.6I20). These indicate that they are highly volatile over the concerned period. As per the table, NLBS has a mean and standard deviation of I0.562I \& I.I635 respectively. CS showed the mean and standard deviation for the given data set is 74.3210 \& I0.0428. CM has experienced a standard deviation equal to I.6596 and means equal to 2.0538. The mean and standard deviation of AQ are 70.1654 \& 9.5064 respectively for the Commercial banks in Bangladesh. For LC mean value is 7.9645 and the standard deviation is 3.4380.

EI has experienced a standard deviation equal to .5453 and means equal to 6.I345. Here the outcome says that all these variable shows less deviation from the mean value. That means that data are more clustered to the mean value.

\subsection{Test of Multi-Collinearatity}

For more reliability of the model, the multi-collinearity test is important. Multi-collinearity is the degree to which one construct can be explained by the other construct in the analysis (Hair et al, 2006). A rule of thumb is that the variance-inflating factor (VIF) of a variable exceeds I0, will be considered to be highly collinear (Kleinbaum, Kupper and muller, I998).

Table 3. Collinearity Statistics

\begin{tabular}{lll}
\hline Variables & Collinearity Statistics & \\
\cline { 2 - 3 } & Tolerance & VIF \\
\hline NLBS & .318 & 3.052 \\
\hline CS & .225 & 4.128 \\
\hline
\end{tabular}




\begin{tabular}{lll}
\hline CA & .350 & 2.540 \\
\hline CM & .765 & 1.135 \\
\hline AQ & .262 & 3.689 \\
\hline LC & .695 & $1.12 \mathrm{I}$ \\
\hline EI & .579 & 1.368
\end{tabular}

Here from the tolerance and variation- inflating factor test (VIF) which is shown in table-3, the values of VIF are found to be less than I0. The tolerance level is also satisfactory because tolerance level does not tend to zero. It means that multi-collinearity does not exist. So there is no major problem for regression analysis.

\subsection{Correlations Analysis}

An attempt has been made here to find the link between the various explanatory variables and dependent variables. This correlation is tested a $5 \%$ level of significance.

Table 4. Correlation Analysis

\begin{tabular}{|c|c|c|c|c|c|c|c|c|c|}
\hline \multicolumn{2}{|c|}{ Variables } & $\mathrm{ROA}$ & NLBS & $\mathrm{CS}$ & $\mathrm{CA}$ & $\mathrm{CM}$ & $\mathrm{AQ}$ & $\overline{\mathrm{LC}}$ & $\overline{E I}$ \\
\hline \multirow{8}{*}{$\begin{array}{l}\text { Pearson } \\
\text { Correlation }\end{array}$} & $\mathrm{ROA}$ & 1.000 & .385 & $.13 \mathrm{I}$ & $.4 \mathrm{I} 3$ & .002 & .012 & $.12 \mathrm{I}$ & .068 \\
\hline & NLBS & $.38 \mathrm{I}$ & 1.000 & -.345 & .598 & -.313 & -.285 & $.05 \mathrm{I}$ & .268 \\
\hline & CS & .139 & -.348 & 1.000 & -.105 & .218 & .789 & $.36 \mathrm{I}$ & $.06 \mathrm{I}$ \\
\hline & $\mathrm{CA}$ & .415 & .651 & -.105 & 1.000 & $-.28 \mathrm{I}$ & .006 & -.007 & $-.09 \mathrm{I}$ \\
\hline & CM & .002 & -.382 & .215 & -.286 & 1.000 & -.279 & .003 & -.182 \\
\hline & $\mathrm{AQ}$ & .012 & -.270 & .839 & .006 & .279 & 1.000 & .259 & $-.01 \mathrm{I}$ \\
\hline & LC &. $\mathrm{I} 2 \mathrm{I}$ & $.05 \mathrm{I}$ & .368 & -.007 & .003 & .259 & 1.000 & .063 \\
\hline & EI & .074 & -.268 & .065 & $-.09 \mathrm{I}$ & -.185 & $.01 \mathrm{I}$ & $.06 \mathrm{I}$ & 1.000 \\
\hline
\end{tabular}

The Table clearly shows that there exists a positive correlation with all the bank-specific variables and profitability which means that the profitability and bank-specific internal factors move in the same direction. At the same time, the macroeconomic variable (EI) that is used in this study also shows a positive correlation with ROA.

\subsection{Regression Analysis}

Here the regression analysis is used through the support of SPSS and result have been shown by the table-05

Table 5. Regression Output

\begin{tabular}{|c|c|c|c|c|c|c|c|c|c|}
\hline \multirow[t]{2}{*}{ Model } & \multirow[t]{2}{*}{$\mathrm{R}$} & \multirow{2}{*}{$\begin{array}{l}\mathrm{R} \\
\text { Square }\end{array}$} & \multirow{2}{*}{$\begin{array}{l}\text { Adjusted R } \\
\text { Square }\end{array}$} & \multirow{2}{*}{$\begin{array}{l}\text { Std. Error } \\
\text { Of the } \\
\text { Estimate }\end{array}$} & \multicolumn{5}{|c|}{ Change Statistics } \\
\hline & & & & & $\begin{array}{l}\text { R Square } \\
\text { Change }\end{array}$ & $\begin{array}{l}\mathrm{F} \\
\text { Change }\end{array}$ & DfI & Df2 & $\begin{array}{l}\text { Sig. F } \\
\text { Change }\end{array}$ \\
\hline $\mathrm{I}$ & .612 & .372 & .286 & 2.10378 & .368 & $4.65 \mathrm{I}$ & 7 & 55 & 000 \\
\hline
\end{tabular}

The analysis here shows that the R-square value is.372 suggests that the predictors are responsible for 37.2 percent of the variance in the result. The model's modified r-square value in .286 shows the true approximation of this model's explanatory power. It is always lower than the value of the $\mathrm{r}$-square. The entire model is important. $(\mathrm{F}=4.65 \mathrm{I}, \mathrm{p}=.000)$

Table 6. Coefficient

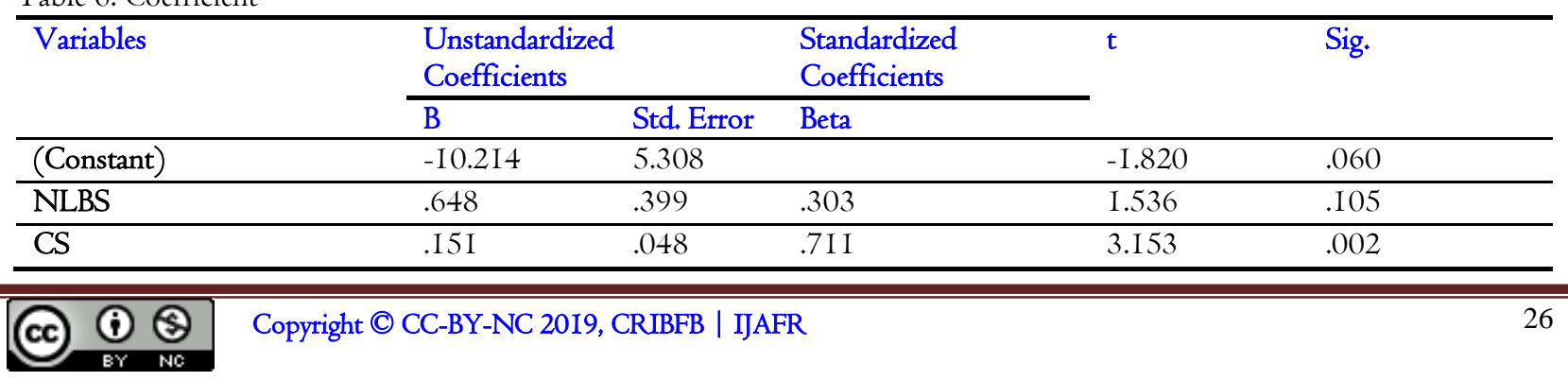




\begin{tabular}{llllll}
\hline CA & .029 & .012 & .351 & 2.165 & $.03 \mathrm{I}$ \\
\hline CM & .308 & .162 & .212 & 1.712 & .076 \\
\hline AQ & -.150 & .054 & -.558 & -2.601 & .008 \\
\hline LC & .001 & $.07 \mathrm{I}$ & .002 & .018 & .978 \\
\hline EI & $.07 \mathrm{I}$ & .568 & .016 & .132 & .868 \\
\hline Dependent Variable: ROA & & & & & \\
\hline
\end{tabular}

According to the outcome of the table-06, it is clear that three variables are imperative here. One variable is CS where B has significantly associated with the profitability because the $\mathrm{P}$-value is less than a $5 \%$ significant level $(\mathrm{P}=.002)$. The second variable is CA, Where the significant level is .03I and the third variable is AQ where the P-value is less than 5\% significant level $(\mathrm{p}=.008)$. So, it is demonstrated that these three factors are the most influential factors that play a major role in the profitability of Commercial Banks.

\section{Conclusion}

The ultimate objective of this paper is not only to identify major banking and macroeconomic factors that can influence profitability but also determine the degree to which the determinants are exercised to influence commercial banks ' profitability in Bangladesh. The internal factors are derived from the bank account and the external factor reflects a bank's business environment. The following conclusions can be drawn from the results of the effect on the competitiveness of the commercial bank in Bangladesh.

The coefficients and their level of significance indicate that the profitability of the commercial banks in Bangladesh is determined by capital structure, capital adequacy and quality of assets.

Bank size, cost management, condition of liquidity and external factor EI has a positive effect on the profitability of banks that are not statistically significant. Both the capital structure and sufficiency of resources contribute positively and objectively to profitability. On the other hand, the quality of assets has a statistically significant impact on profitability. Based on empirical findings, the banks ' size cannot lead to an increase in profitability, whether small or large, for commercial banks. You will improve your productivity by handling your investment and your assets effectively. In the case of commercial banks in Bangladesh, investment and productivity are also inverse.

\section{Recommendation}

The demonstration of this paper is desperately policy-relevant. To improve the profitability a long term adjustment is required in the variables. Here further extension can be done by incorporating both conventional and Islamic shariah based banks. More bank-specific factors like - non-interest expense, interest rate, credit risk, CSR activities, and the number of branches, and industry-specific variable like industry concentration level; and eternal macro-economic variables like-, inflation, and interest rate, call money rate can be considered into future research to get and more appropriate results. This paper will be supportive of the bank's investor, policymaker, researcher, management, bankers and stakeholders for improved decision making and better performance of their organizations.

\section{References}

Acaravci, S. K., \& Çalim, A. E. (2013). Turkish banking sector's profitability factors. International Journal of Economics and Financial Issues, 3(I), 27-4I.

Bangladesh Bank. (2018). Retrieved from Bangladesh bank web site http://www.bb.org.com

Dey, M. (20I4). Profitability of commercial banks in Bangladesh: a multivariate analysis. IOSR Journal of Business and Management (IOSR-JBM), I6 (4), 92-95.

Gul, S., Irshad, F., \& Zaman, K. (20II). Factors Affecting Bank Profitability in Pakistan. Romanian Economic Journal, I4(39).

Hossain, M. S., \& Ahamed, F. (2015). Determinants of bank profitability: A study on the banking sector of Bangladesh. Journal of Finance and Banking, I3(I), 43-57.

Kleinbaum, D. G., Kupper, L. L., \& Muller, K. E. (I998). Applied regression analysis and other multivariable methods. -PWS.

Krishnaswany, K.N., Savilkumar, A., \& Mathirajan, M., (20I I). Management Research Methodology, Integration of principle Method and Techniques. Delhi: Pearson education in South Asia.

Mirzaei, A., \& Mirzaei, Z. (20II). Bank-specific and macroeconomic determinants of profitability in middle eastern banking. Iranian Economic Review, I5(29), IOI-I28.

Nisar, S., Susheng, W., Jaleel, A., \& Ke, P. (2015). Determinants of bank's profitability in Pakistan: A latest panel data evidence. International Journal of Economics, Commerce and Management, 3(4). 
Noman, A. H. M. (2015). An empirical investigation of the profitability of Islamic banks in Bangladesh. Global Journal of Management And Business Research.

\section{Copyrights}

Copyright for this article is retained by the author(s), with first publication rights granted to the journal. This is an open-access article distributed under the terms and conditions of the Creative Commons Attribution license (http://creativecommons.org/licenses/by/4.0/). 